\title{
OFTALMOMIAZE்: PAPLITIMAS, EIGA, DIAGNOSTIKA IR GYDYMAS
}

\author{
Indrè Rašinskaite் ${ }^{1}$, Rasa Strupaitė-Šileikiene $\dot{e}^{1,2}$, Rimvydas Stanislovas Ašoklis ${ }^{1,2}$ \\ ${ }^{1}$ Vilniaus universiteto Medicinos fakultetas, ${ }^{2}$ Vilniaus universiteto Medicinos fakultetas, \\ Klinikinès medicinos institutas, Ausu, nosies, gerklès ir akiu ligu klinika, Akiu ligu centras
}

Raktažodžiai: oftalmomiazè, musių lervos, akių miazè.

\section{Santrauka}

İvadas. Oftalmomiazė arba akių miazè yra reta infekcinè akių liga, kurią sukelia dvisparnès (diptera) musių lervos. Dažniausias sukèlèjas yra O.ovis musių rūšis, paplitusi tropinèse, subtropinèse vietose ir Viduržemio jūros regione. Išskiriamos trys oftalmomiazès formos: išorinè, vidinè ir akiduobės. Simptomų sunkumas varijuoja nuo lengvo akies sudirginimo iki visiškos akies audinių destrukcijos. Ligos diagnostika remiasi lervos identifikacija akyje ar aplinkiniuose audiniuose. Organizmų pašalinimas iš akies yra pagrindinis gydymo būdas. Specifinio medikamentinio gydymo nèra, skiriama antimikrobiné ir uždegimo slopinamoji terapija, kai kuriais atvejais antihelmintiniai vaistai. Visuotinis klimato atšilimas ir intensyvus žmonių turizmas didina šios infekcijos tikimybę Lietuvoje.

Tikslas - apžvelgti literatūros duomenis apie oftalmomiazès epidemiologiją, etiologiją, diagnostikos ir gydymo būdus ir supažindinti įvairių specialybių gydytojus su šia liga.

Metodai. Publikacijų paieška atlikta PubMed, UpToDate, MedScape medicininėse duomenų bazèse. Atrinkti straipsniai, kuriuose buvo aprašyti klinikiniai atvejai arba klinikinių atvejų serijos oftalmomiazès tema. Nagrinèti straipsniai nuo 1980 iki 2021 metu.

Išvados. Gydytojai turètų būti susipažinę su infekcine oftalmomiazès liga, kadangi ji sutinkama ne tik tropiniuose regionuose, bet ir Europos valstybėse, o aktyvus žmonių turizmas didina atvejų tikimybę Lietuvoje. Oftalmomiazė yra reta liga, neretai klaidingai diagnozuojama kaip alerginis ar virusinis konjunktyvitas, akies miežis, todèl itin svarbus kruopštus anamnezès surinkimas ir oftalmologinis ištyrimas, kad būtų laiku pradètas gydymas. Išorinès oftalmomiazès gydymas yra nesudètingas, o ligos baigtis gera. Akiduobès oftalmomiazė yra greitai progresuojanti destrukcinè akies parazitozè, todèl laiku atliktas organizmų pašalinimas apsaugo akị ir aplinkinius audinius nuo pažeidimo. Rekomenduojama pakartotinè paciento apžiūra, siekiant patikslinti, ar liga nemanifestuoja ir nèra papildomų komplikacijų.

\section{Ivadas}

Oftalmomiazė yra reta infekcinè akių liga, sudaranti 5-14 proc. visų žmogaus miazių [1]. Žodis miazė (graik. myia) reiškia musè. Terminas oftalmomiazè, kaip parazitinè musių sukelta akių infekcija, pirmą kartą pavartotas F. Hope 1840 metais [2]. Ligą sukelia dvisparnių musių (diptera) lervos, patekusios ị akị ir aplinkinius jos audinius. Anatominès medicinos sistemoje oftalmomiazè klasifikuojama i i išorinę, vidinę ir akiduobès. Pagrindinis oftalmomiazès sukèlèjas yra musių rūšis (Oestrus ovis) [3]. Kliniškai liga dažnai klaidingai diagnozuojama kaip virusinis ar alerginis konjunktyvitas, nes pasireiškia panašiais simptomais: hiperemija, dirginimo pojūčiu ir svetimkūnio jausmu [4]. Infekcija labiausiai paplitusi tropiniuose ir subtropiniuose regionuose, kur beveik visus metus šiltas ir drègnas klimatas, taip pat besivystančiose šalyse, kuriose didelis gyventojų tankis ir prastos higienos sąlygos [5]. Dèl intensyvèjančio turizmo ir vis dažnesnių oftalmomiazès atvejų neendeminėse šalyse, ligos sukèlèjų paplitimo Europos valstybėse, svarbu žinoti apie oftalmomiazę, mokèti ją atpažinti, diagnozuoti ir gydyti. Straipsnių lietuvių kalba šia tema nepavyko rasti, todèl ši apžvalga yra aktuali kiekvienam gydytojui.

Tyrimo tikslas - remiantis mokslinès literatūros duomenimis, aprašyti oftalmomiazès epidemiologiją, etiologiją, klinikini pasireiškimą, diagnostikos ir gydymo galimybes.

\section{Tyrimo medžiaga ir metodai}

Publikaciju paieška atlikta PubMed, UpToDate, MedScape medicininėse duomenų bazèse. Atrinkti straipsniai, kuriuose buvo aprašyti klinikiniai atvejai arba klinikinių atvejų serijos oftalmomiazès tema. Nagrinèti straipsniai nuo 1980 iki 2021 metų. 


\section{Tyrimo rezultatai}

Anatominė klasifikacija. Priklausomai nuo parazito invazijos į akies audinius, išskiriamos trys oftalmomiazès rūšys: 1. Išorinė akių miazė (IOM) apima paviršinius akies audinius. Pažeidžiama junginė arba ragena [6]. Infekcija gali komplikuotis ir i ašarų liaukos miazę. 2. Vidinè oftalmomiazè (VOM) apima priekinị arba užpakalinị akies obuolio segmentus. Esant priekinei VOM, lervos stebimos priekinëje kameroje, esant užpakalinei VOM - stiklakūnyje arba subretininiame tarpe [7]. 3. Akiduobès oftalmomiazė (AOM) atsiranda, kai infekcija apima ne tik akies obuoli, bet ir aplinkinius akiduobès audinius [8].

Taksonominė klasifikacija. Diptera yra didelis dvisparnių vabzdžių būrys, dar žinomas kaip tikrosios musès. Būrys sudarytas iš 150000 rūšių, 10000 genčių ir 150 šeimų, kuriu didžioji dalis yra ligų pernešejai. Dvisparniai skirstomi ị du didelius pobūrius: Nematocera ir Brachycera. Nematocera pobūrio didžiają dalị sudaro kraujasiurbiai, pernešantys įvairias virusines, pirmuonių ir helmintų sukeliamas ligas. Brachycera pobūrio rūšys sukelia specifines miazes, tarp jų ir oftalmomiazę bei daugeli fakultatyvinių miazių [9]. Organizmų identifikacija yra svarbi nuspèti galimą komplikacijų riziką, nes kai kurios rūšys gali patekti gilyn ị akies obuolị ir sukelti iridociklitą bei endoftalmitą [10].

Etiologija ir patogenezè. IOM pagrindinis sukèlèjas yra O.ovis, dar vadinamas nosies kirminu. Tai Diptera rūšies Oestridae šeimos muse, kurios natūralūs šeimininkai yra avys ir ožkos. Suaugusios musès gyvenimo ciklas yra 10 dienų. Per tą laiką ji padeda kiaušinèlius gyvulių nosies ertmèje.

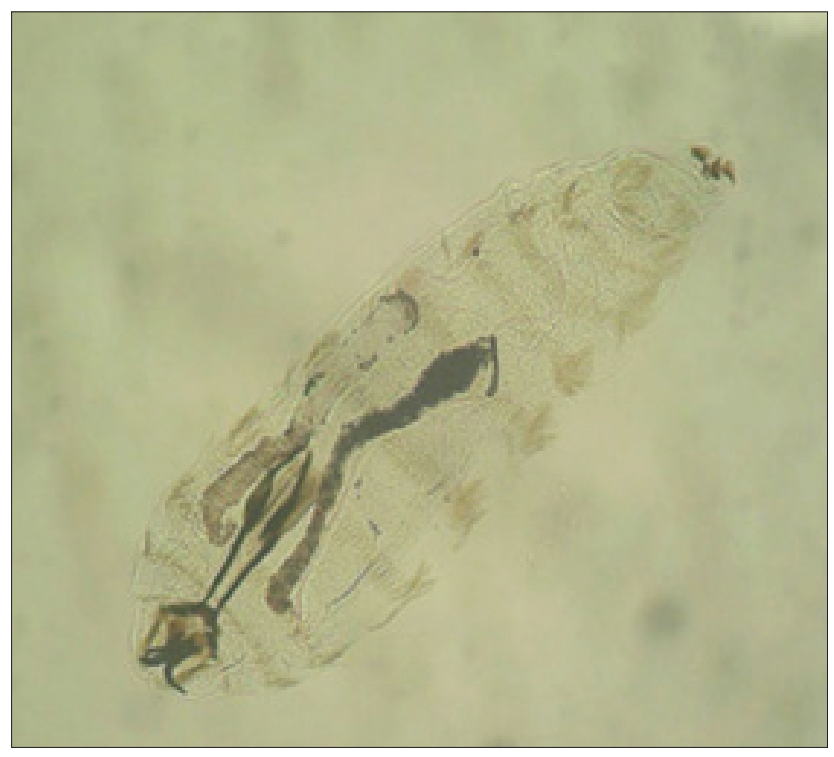

1 pav. O. ovis pirmos stadijos lerva [12]
Išsiritusios lervos migruoja ị nosies sinusus, kur subręsta iki 3 stadijos. Tuomet patenka ị dirvožemị, kuriame bręsta iki suaugusios musès. Žmogus yra atsitiktinis šeimininkas, kai musè sporadiškai padeda kiaušinèlius ant akies obuolio [10]. O.ovis neišskiria proteolizinių fermentų, todèl negali patekti ị gilesnius akies audinius ir sukelia tik IOM. Žmogaus audiniuose lervos negali vystytis iki galutinès stadijos, todèl manoma, kad per dešimt dienų jos žūva, jeigu nèra pašalinamos [11]. Parazitai yra apie $1 \mathrm{~mm}$ ilgio, permatomi, ar balkšvos spalvos, turi tamsesnę galvinę dali ir joje esančius juodus kabliukus, kuriais ịsikabina ị audinius (1 pav.) [10]. Hypoderma tarandi (H. tarandi) natūralūs šeimininkai yra elniai. AOM dažniausiai sukelia Calliphoridae rūšies musès.

Epidemiologija. Miazè yra zoonozinè liga, nustatoma atokiose kaimo vietose ir rečiau miestuose. Ji ypač dažna besivystančiose šalyse, kur prastos higienos sąlygos. Dèl didejančio žmonių judumo infekcija sutinkama ir neendeminèse zonose [13]. O.ovis pasauliniu mastu yra dažniausias oftalmomiazès sukèlèjas. Jis paplitęs šiltuose Viduržemio jūros regionuose, Azijoje ir Amerikoje [12]. A. Bakrač ir kiti atlikto tyrimo rezultatai parode, kad beveik pusė O. ovis sukeltos akių miazės atvejų yra užregistruoti miestuose. Apie pusė pacientų teigè, kad neturejjo jokio sąlyčio su gyvuliais. Daroma prielaida, kad kaimo vietovèse didesnis atvejų skaičius, apie kuriuos nepranešama. Itin didelis infekcijos paplitimas miestuose aiškinamas zooprofilaktikos reiškiniu, kai susidaro didesnè oftalmomiazès infekcijos tikimybe, nes nèra alternatyvių natūralių šeimininkų, tik žmogus, kuriam ir sukeliama infekcija [14]. J. Landehag ir kt. klinikinių atvejų serijos tyrime aprašyti 39 oftalmomiazès atvejai Norvegijoje, kurių sukèlejjas buvo $H$. tarandi musių rūšis. Ši rūšis

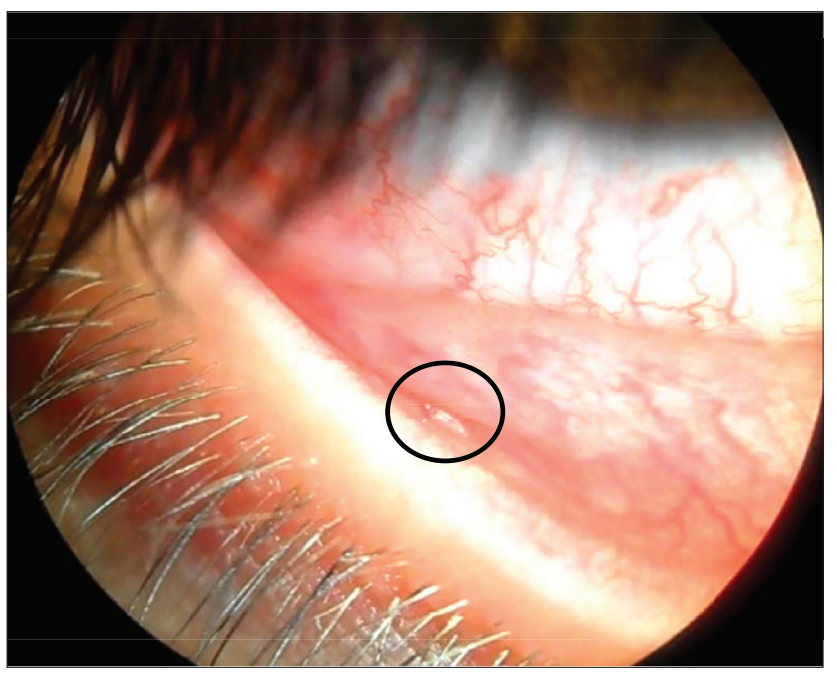

2 pav. O.ovis lerva akies obuolio junginèje [3] 
randama Suomijoje, Švedijoje, Kolos pusiasalyje Rusijoje. Dažniausiai H. tarandi atvejai nustatomi rugsejjo-gruodžio mènesiais [15]. O. ovis musès labiausiai aktyvios nuo pavasario iki vèlyvo rudens [16].

Rizikos veiksniai. Predisponuojantys veiksniai yra vyresnis amžius, lètinès ligos, vèžiniai susirgimai, ŽIV infekcija. Svarbus veiksnys yra prasta asmens higiena ir bendroji sveikatos būklè, anamnezèje buvęs artimas sąlytis su naminiais gyvuliais [8]. AOM asocijuota su piktybiniais akių odos navikais, buvusiomis akių traumomis, operacijomis, tokiomis kaip evisceracija (pašalinamas akies obuolio turinys). Šios būklès dažnai sukelia išopėjimus, nekrozinių masių buvimą [13], o tai pritraukia muses.

Klinikinė eiga. Dažniausiai aprašoma IOM forma. Iprastai žmogus pirmiausia pajaučia, kad vabzdys ar svetimkūnis pateko ị akị. Pirmieji simptomai dažniausiai būna nespecifiniai ir išsivysto per kelias valandas. Atsiranda niežulys, svetimkūnio akyje jutimas, fotofobija, ašarojimas, vèliau junginès paraudimas ir edema (2 pav.) [17]. Neretai skausminga uždegiminè reakcija diagnozuojama kaip ūminis konjunktyvitas [18]. Lervos gali migruoti ị nosies ertmę ir sukelti rinitą [17].

H. tarandi sukelia akies ir aplinkinès odos patinimą, kuriame stebimas juodas taškas - lervos kvėpuojamoji anga [15]. D.hominis sukelta IOM pasireiškia niežuliu, odos edema ir neretai skausmu, sukeltu judančios lervos. Būklè neretai klaidingai diagnozuojama kaip miežis, jei patinimas nedidelis, arba preseptalinis celiulitas, jei patinimas sunkus [11].

Kur kas sunkesné eiga yra VOM, kurio simptomai yra regos sutrikimas, akies skausmas, skotomos [3].

AOM ligos eiga yra destruktyvios formos. Ankstyvas jos nustatymas leidžia išvengti lervų prasiskverbimo ị gilesnius akies audinius, nosies sinusus ir kaukolès ertmę [19]. Didelis parazitų skaičius ir invazija ị audinius vystosi labai greitai ir per kelias dienas gali sukelti akies destrukciją ir aklumą. Dažniausiai pažeidimas yra vienpusis. Lervų skaičius būna nuo kelių dešimčių iki kelių šimtų. Tai blogesnès prognozès požymis. Beveik visais AOM atvejais akies srityje yra odos išopejjimų ar žaizdų. Prie šių pažeidimų prisideda uždegimo simptomai: akies, voko paraudimas, patinimas, skausmas, niežulys ir jausmas, kad kažkas akyje juda [13].

Diagnostika. Diagnostika remiasi lervos akyje nustatymu. Apžiūrint akis dažniausiai yra paraudusi, galimas akies voko patinimas ir eritema [3]. Atliekant biomikroskopiją, itin reikšmingas radinys yra taškinès junginès mikrohemoragijos [12]. Lervos yra fotofobiškos. Dèl ant priekinio galo esančių fotoreceptorių juda nuo šviesos šaltinio gilyn ị audinius [19]. Klasikinis konjunktyvitas, pseudomembraninis konjunktyvitas, keratouveitas yra ligai būdingi diagnostiniai požymiai [8].
VOM atveju išorinio akies pažeidimo dažnai nebūna. Atliekant biomikroskopiją ir akies dugno apžiūrą nustatomas iridociklitas, tinklainès ir stiklakūnio hemoragijos. Itin reikšmingas požymis - linijiniai subretininiai lervų takai. Galima tinklainès atšoka, o sunkiais atvejais išsivysto endoftalmitas ir panuveitas [8].

Visais atvejais svarbu patikrinti regejjimo aštrumą, apžiūrèti priekinį ir užpakalinị akies segmentus [10]. AOM atvejais dažniausiai nustatomas tik šviesos jutimas [13]. Siekiant nustatyti pažeidimo apimtí, atliekami papildomi radiologiniai tyrimai.

Pašalinti organizmai patalpinami ị etilo alkoholi (70\%) ir išsiunčiami ị laboratoriją morfologinei identifikacijai [1]. Jeigu organizmas pašalinimo metu buvo pažeistas ar yra tik jo dalys, etmologinis identifikavimas galimas nustatant DNR brūkšninį kodą [20].

Gydymas. Gydymo taktika priklauso nuo pažeidimo vietos ir lygio. Pirminè IOM ir AOM gydymo taktika yra mechaninis lervų pašalinimas, naudojant plyšinę lempą ir medicininị pincetą [8]. Prieš tai skiriamas vietinis anestetikas, kuris paralyžiuoja ir imobilizuoja parazitus. Literatūroje aprašomi anestetikai yra proparacaino hidrochlorido $(0,5 \%)$ lašai, terpentino aliejus, o skystas parafinas sukelia lervos asfiksiją. Ksilokainas ir kokainas paralyžiuoja organizmus, neleidžia plisti gilyn ị audinius, palengvina jų pašalinimą [13]. Kad akyje neliktų musių kiaušinèlių, rekomenduojama akis išplauti fiziologiniu ar druskos tirpalu.

VOM gydoma atliekant lazerio fotokoaguliaciją ir vitrektomiją. S. Fung ir kt. aprašè atveji, kai $12 \mathrm{~m}$. mergaitei su užpakaline VOM buvo atlikta organizmo fotodestrukcija Nd:YAG lazeriu. Lerva buvo subhialoidiniame tarpe (tarp stiklakūnio ir tinklainès). Šis gydymo pasirinkimas nesukèlè vèlesnių komplikacijų ir nebuvo atlikta vitrektomija. Skirtingai yra taikant fotokoaguliaciją argono lazeriu, kuomet termiškai sunaikinti organizmą reikia didesnio lazerio taškų skaičiaus, o ateityje tikètinas gyslainès neovaskulinès membranos išsivystymas. Po vitrektomijos neretai susidaro tinklainès atšoka ir subretininès hemoragijos [7].

Remiantis literatūra, jeigu didelis lervų kiekis AOM metu patenka ị akies obuolị, dažniausiai atliekama enukleacija (akies obuolio pašalinimo operacija), siekiant efektyviai kontroliuoti infekciją. Kai parazitai pasiekia akiduobès viršūnę ir sukelia masyvią akiduobès audinių destrukciją, atliekama akiduobės eksenteracija. Negydoma infekcija plinta ị akiduobės kaulus, prienosinius sinusus, per akiduobès viršūnę i kaukolès vidinius audinius, o tai lemia fatališką baigti [13].

Nèra specifinio oftalmomiazès gydymo. Skiriami vietiniai antibiotikai (chinolonai arba aminoglikozidai), kad būtų išvengta antrinès bakterinès infekcijos, vietiniai nesteroidiniai vaistai nuo uždegimo arba kortikosteroidai, siekiant suma- 
žinti uždegiminę reakciją $[8,10]$. Vienkartinès peroralinès plataus spektro vaisto nuo parazitų Ivermektino $200 \mathrm{mcg} / \mathrm{kg}$ dozès skyrimas apsaugo nuo lervų invazijos ị akies audinius. Vaistas yra saugus, tačiau nèra skiriamas rutiniškai $[10,13]$.

Ligos baigtis. Negydoma oftalmomiazè progresuoja dienomis. Galima junginès folikulinė reakcija, pseudomembranų susidarymas, ragenos infiltracija ir priekinis uveitas. Antrine bakterinė infekcija gali sukelti preseptalinị celiulitą, užpakalinị uveitą, endoftalmitą [21].

\section{Išvados}

1. Gydytojai turi būti susipažinę su infekcine oftalmomiazès liga, kadangi ji sutinkama ne tik tropiniuose regionuose, bet ir Europos valstybėse, o aktyvus žmonių turizmas didina atvejų tikimybę Lietuvoje.

2. Oftalmomiazė yra reta liga, neretai klaidingai diagnozuojama kaip alerginis ar virusinis konjunktyvitas, akies miežis, todèl itin svarbus kruopštus anamnezès surinkimas ir oftalmologinis ištyrimas, kad būtų laiku pradètas gydymas.

3. Išorinès oftalmomiazès gydymas yra nesudètingas, o ligos baigtis gera.

4. Akiduobės oftalmomiazè yra greitai progresuojanti ir destrukcinè akies parazitozé, todèl laiku atliktas organizmų pašalinimas leidžia išvengti didesnio akies ir aplinkinių audinių pažeidimo ir apsaugoti akị.

5. Rekomenduojama pakartotinė paciento apžiūra patikslinti, ar liga nemanifestuoja ir nėra papildomų komplikacijų.

\section{Literatūra}

1. Puthran N, Hegde V, Anupama B, Andrew S. Ivermectin treatment for massive orbital myiasis in an empty socket with concomitant scalp pediculosis. Indian J Ophthalmol 2012;60(3):225-227.

https://doi.org/10.4103/0301-4738.95880

2. Ziemianski MC, Lee Ky, Sabates FN. Ophthalmomyiasis interna. Arch Ophthalmol 1980;98:1588-9.

https://doi.org/10.1001/archopht.1980.01020040440008

3. Istek Ş. Ophthalmomyiasis externa from Hakkari, the south east border of Turkey. BMJ Case Rep 2014;2014.

https://doi.org/10.1136/bcr-2013-201226

4. Velev V, Mikov O. Ophthalmomyiasis caused by larvae of the parasite Oestrus ovis. QJM 2018;111:727-8.

https://doi.org/10.1093/qjmed/hcy106

5. Bhola N, Jadhav A, Borle R, Adwani N, Khemka G, Jadhav P. Primary Oral Myiasis: A Case Report. Case Rep Dent 2012. https://doi.org/10.1155/2012/734234

6. Kalezić T, Stojković M, Vuković I, Spasić R, Andjelkovic M, Stanojlović S, et al. Human external ophthalmomyiasis caused by Lucilia sericata Meigen (Diptera: Calliphoridae)--a green bottle fly. J Infect Dev Ctries 2014;8:925-8. https://doi.org/10.3855/jidc.4552

7. Fung SSM, West SJ, MooreAT. Ophthalmomyiasis interna masquerading as orbital cellulitis. Journal of American Association for Pediatric Ophthalmology and Strabismus 2016;20:546-548.e2. https://doi.org/10.1016/j.jaapos.2016.07.228

8. Özyol P, Özyol E, Sankur F. External ophthalmomyiasis: a case series and review of ophthalmomyiasis in Turkey. Int Ophthalmol 2016;36:887-91.

https://doi.org/10.1007/s10792-016-0204-9

9. Francesconi F, Lupi O. Myiasis. Clin Microbiol Rev 2012;25:79105.

https://doi.org/10.1128/CMR.00010-11

10. Tabuenca-del Barrio L, Mozo-Cuadrado M, Zubicoa-Eneriz A, Plaza-Ramos P. Ocular external myiasis. A series of cases due to larvae Oestrus ovis in Navarra, Spain. Arch Soc Esp Oftalmol. Elsevier 2018;93:567-70. https://doi.org/10.1016/j.oftale.2018.05.018

11. Sreejith RS, Reddy AK, Ganeshpuri SS, Garg P. Oestrus ovis ophthalmomyiasis with keratitis. Indian J Med Microbiol 2010;28:399-402. https://doi.org/10.4103/0255-0857.71846

12. Carrillo I, Zarratea L, Suárez MJ, Izquierdo C, Garde A, Bengoa A. External ophthalmomyiasis: a case series. Int Ophthalmol 2013;33:167-9. https://doi.org/10.1007/s10792-012-9644-z

13. Huang Y-L, Liu L, Liang H, He J, Chen J, Liang Q-W, et al. Orbital myiasis: A case report and literature review. Medicine (Baltimore) 2020;99:e18879. https://doi.org/10.1097/MD.0000000000018879

14. Pupić-Bakrač A, Pupić-Bakrač J, Škara Kolega M, Beck R. Human ophthalmomyiasis caused by Oestrus ovis-first report from Croatia and review on cases from Mediterranean countries. Parasitol Res 2020;119:783-93.

https://doi.org/10.1007/s00436-019-06599-x

15. Landehag J, Skogen A, Åsbakk K, Kan B. Human myiasis caused by the reindeer warble fly, Hypoderma tarandi, case series from Norway, 2011 to 2016. Euro Surveill 2017;22. https://doi.org/10.2807/1560-7917.ES.2017.22.29.30576

16. Zhang A, Nie Q, Song J. External ophthalmomyiasis caused by Oestrus ovis in east China. Trop Doct 2018;48:169-71. https://doi.org/10.1177/0049475517737456

17. Arslan F, Mete B, Oztürk R, Samasti M. External ophthalmomyiasis caused by Oestrus ovis in Istanbul. Trop Doct 2010;40:186-7.

https://doi.org/10.1258/td.2010.090464

18. Choi W, Kim GE, Park SH, Shin SE, Park JH, Yoon KC. First report of external ophthalmomyiasis caused by Lucilia sericata Meigen in a healthy patient without predisposing risk factors. Parasitol Int 2015;64:281-3.

https://doi.org/10.1016/j.parint.2015.03.002

19. Kalamkar C, Radke N, Mukherjee A. Orbital myiasis in evisce- 
rated socket and review of literature. BMJ Case Rep 2016;2016. https://doi.org/10.1136/bcr-2016-215361

20. Rukke BA, Cholidis S, Johnsen A, Ottesen P. Confirming Hypoderma tarandi (Diptera: Oestridae) human ophthalmomyiasis by larval DNA barcoding. Acta Parasitol 2014;59:301-4. https://doi.org/10.2478/s11686-014-0242-2

21. Jenkins KS, Layton CJ. External ophthalmomyiasis caused by Oestrus ovis. Clin Exp Ophthalmol 2018;46:300-1. https://doi.org/10.1111/ceo.13033

\section{OPHTHALMOMYIASIS: PREVALENCE, PROCESS, DIAGNOSIS AND TREATMENT}

I. Rašinskaitė, R. Strupaitė-Šileikienė, R.S. Ašoklis

Keywords: ophthalmomyiasis, fly larvae, ocular myiasis. Summary

Introduction: Ophthalmomyiasis, or ocular myiasis, is a rare infectious eye disease caused by the larvae of Diptera flies. The most common causative agent is the fly species Oestrus ovis, which is common not only in tropical and subtropical areas but also in the Mediterranean region. There are three forms of ophthalmomyiasis: external, internal and orbital. The severity of symptoms varies from mild irritation of the eye to complete destruction of the ocular tissues. Diagnosis of the disease is based on the identification of the larva in the eye or surrounding tissues. Removal of the organisms from the eye is the main treatment. There is no specific medical treatment, antimicrobial and anti-inflammatory therapies are prescribed, and in some cases antihelminthic drugs. Global war- ming and intensive human tourism increase the likelihood of this infection in Lithuania.

Aim: To review scientific literature on the epidemiology, aetiology, diagnosis and treatment of ophthalmomyiasis and to introduce the disease to physicians of different specialties.

Methods: PubMed, UpToDate, MedScape medical databases were searched. Articles describing clinical cases or case series on the topic of ophthalmomyiasis were selected. Articles from 1980 to 2021 were analysed.

Conclusions: Physicians should be familiar with the infectious disease of ophthalmomyiasis, as it occurs not only in tropical regions but also in European countries, and active human tourism increases the probability of cases in Lithuania. Ophthalmomyiasis is a rare disease, often misdiagnosed as allergic or viral conjunctivitis, or chalazion, therefore careful history taking and ophthalmological examination are essential to ensure timely treatment. Treatment of external ophthalmomyiasis is uncomplicated and the outcome of the disease is good. Ophthalmomyiasis of the orbit is a rapidly progressive and destructive parasitosis of the eye, and timely removal of the organisms can prevent further damage to the eye and surrounding tissues and protect the eye. Re-examination of the patient is recommended to look for manifestations and additional complications.

Correspondence to: indre.ras@gmail.com

Gauta 2021-05-19 